This item was submitted to Loughborough's Research Repository by the author.

Items in Figshare are protected by copyright, with all rights reserved, unless otherwise indicated.

\title{
Large-scale compatible methods for the preservation of human embryonic stem cells: current perspectives
}

PLEASE CITE THE PUBLISHED VERSION

http://dx.doi.org/10.1002/btpr.680

\section{PUBLISHER}

Wiley (@ American Institute of Chemical Engineers (AIChE)

VERSION

SMUR (Submitted Manuscript Under Review)

\section{LICENCE}

CC BY-NC-ND 4.0

\section{REPOSITORY RECORD}

Coopman, Karen. 2014. "Large-scale Compatible Methods for the Preservation of Human Embryonic Stem Cells: Current Perspectives”. figshare. https://hdl.handle.net/2134/14247. 
This item was submitted to Loughborough's Institutional Repository (https://dspace.lboro.ac.uk/) by the author and is made available under the following Creative Commons Licence conditions.

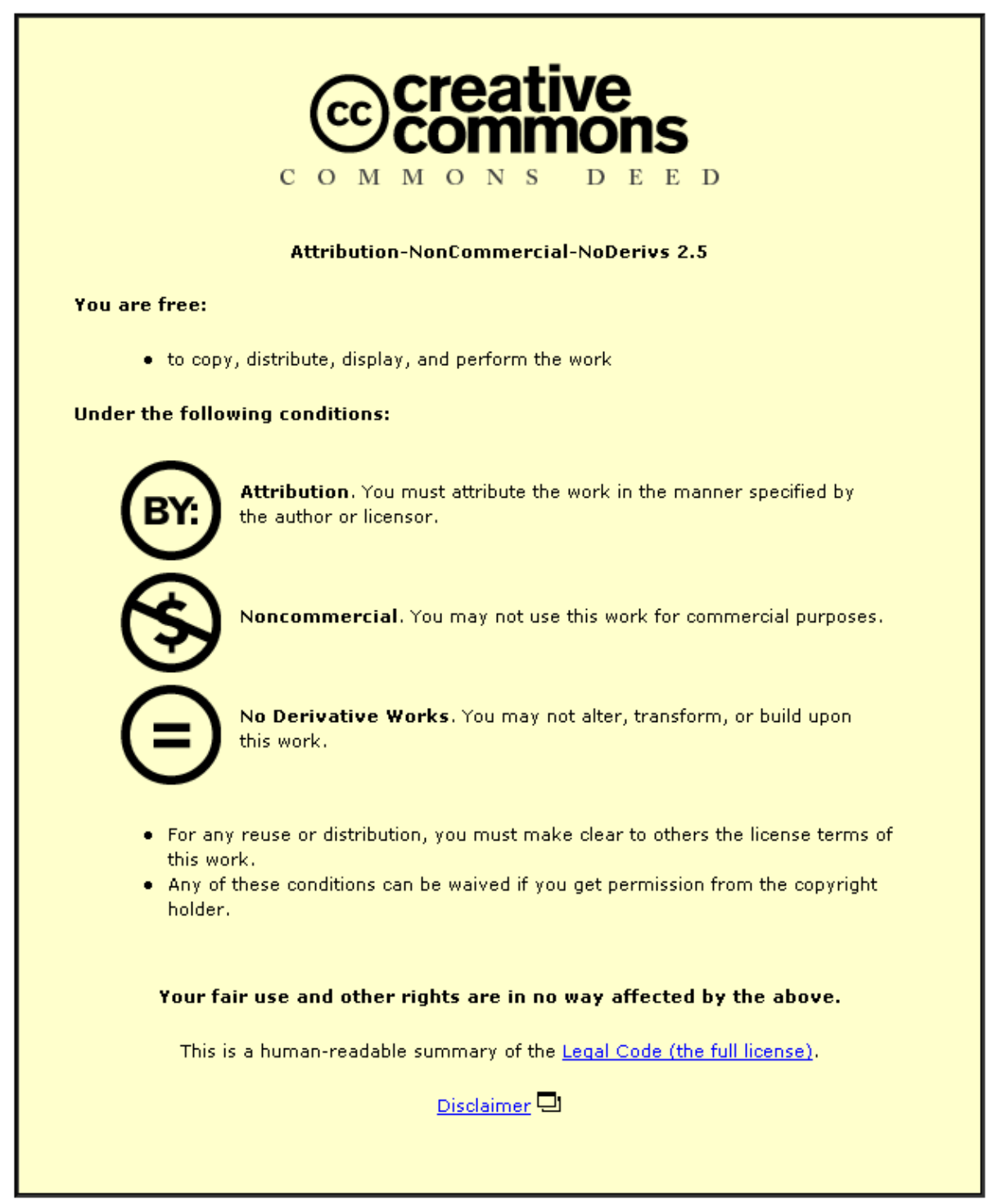

For the full text of this licence, please go to: http://creativecommons.org/licenses/by-nc-nd/2.5/ 
Title: Large scale compatible methods for the preservation of human embryonic stem cells: current perspectives

Author list: Karen Coopman*

* author to whom correspondence should be addressed

Address: Centre for Biological Engineering, Department of Chemical Engineering, Loughborough University, Loughborough, LE11 3TU, UK, telephone 0044 (0)1509 222513, fax 0044 (0)1509 223923, e-mail k.coopman@lboro.ac.uk

Key words: human embryonic stem cells, cryopreservation, scale-up, vitrification, conventional slow freezing 


\section{Abstract:}

Human embryonic stem cells (hESCs) and hESC-derived cells are of great interest, not only because of their therapeutic potential, but also their prospective uses in in vitro drug and toxicity screening. The ability to preserve these cells is critical, allowing for the generation of quality controlled stocks of cells, transport of cells between sites and avoiding the need for expensive and time consuming continuous culture. Current methodologies, namely conventional slow freezing and vitrification, can successfully preserve hESCs and their differentiated progeny, retaining the key characteristics of the cells. However, there is a significant gap between the number of cells potentially needed to either treat patients or run a high-throughput drug screen and how many cells can be preserved using these techniques. Therefore, this review focuses on the scalability of slow freezing and vitrification, identifying key barriers to success and whether they can be overcome. Given the precedent with other mammalian cells in using slow freezing to successfully preserve large quantities of cells, and its compatibility with current and emerging culture methods for hESCs, it is likely to become the method of choice for cryopreserving these cells at scale. However, issues other than scale still exist, therefore alternatives to cryopreservation should also be explored. Here, the potential to lyophilise hESCs for long-term storage is considered as one such alternative. 


\section{Introduction}

Human embryonic stem cells (hESCs) hold great promise in the field of regenerative medicine. These cells have the ability to self-renew and are pluripotent, meaning that, given the right stimulus, they have the ability to differentiate into almost any cell type of the body, such as cardiomyocytes, pancreatic $\beta$-cells, hepatocytes or neurons. The potential of such hESCderived cells as therapeutic agents has recently been highlighted by the start of some long-awaited clinical trials in both the UK and USA. ${ }^{1}$ Human ESCs and hESC-derived cells are also of great interest for the in vitro study of: development, genetic disorders ${ }^{2}$ and use in drug discovery or toxicology studies. ${ }^{3,4}$ For example, a high-throughput screen (HTS) was recently used to identify compounds that regulate hESC self-renewal and differentiation, ${ }^{5}$ supporting the use of these cells in HTS assays. In another study it was found that hESC-derived cardiomyocytes can accurately indicate some adverse drug effects. ${ }^{6}$ This suggests that if further developed, such systems could be used in drug safety testing as well as initial drug screening, potentially cutting down on the need for some animal testing. Indeed, hESCderived cardiomyocytes for in vitro assays can now be purchased from a commercial source.

Human ESCs are dependent on attachment to a matrix, provided by either a feeder layer of cells or an extracellular matrix substitute, for growth. Typically, they are grown as colonies in planar culture, although growth in monolayer culture can also be achieved..$^{7-10}$ It has been estimated that $10^{9}$ cardiomyocytes are needed to repair a single infarcted heart, ${ }^{11}$ but given the current inefficiency of both differentiation and separation protocols, the number of hESCs needed is likely to be closer to $10^{13}$. Thus, in order to meet the potential demand for these cells, much of the current hESC research is focused on developing defined and scalable culture methods as well as directing differentiation in order to generate relevant cell types. However, it is also important to consider how, once produced, both hESCs and their derived products will be preserved at scale. 
As discussed in more detail in Section 2, preservation of these cells is critical to storing high quality stocks for either clinical or in vitro applications. Figure 1 shows that cells can be preserved at different points along the manufacturing process. The most widely used technique for long-term preservation of mammalian cells is cryopreservation, with cells stored directly in liquid nitrogen $\left(-196^{\circ} \mathrm{C}\right)$ or its vapour phase $\left(-150^{\circ} \mathrm{C}\right)$. Human ESCs or their differentiated progeny are frequently cryopreserved by conventional slow freezing methods, adapted from protocols used for mouse ESCs and other mammalian cells. Slow freezing methods can allow the preservation of cells in a range of containers from $1 \mathrm{ml}$ vials to 50-100 ml bags. In contrast, vitrification, a rapid freezing method widely used for preservation of embryos, has also been used to preserve hESC colonies ${ }^{12}$ but is generally conducted at a much smaller scale. The so-called open pulled straw (OPS) method is most commonly used where clumps of hESCs in 1-20 $\mu \mathrm{l}$ of medium are stored in specialised cryostraws. ${ }^{12}$

Although the numbers of cells/dose needed is disease-dependent, $10^{6}-10^{9}$ cells are typically required per patient, ${ }^{13}$ with disease prevalence further determining the total number of cells required per year. Similarly, at the current seeding densities used, approximately $6 \times 10^{9}$ cells would need to be plated in order to screen a library of 1 million compounds in a HTS campaign. 5 Even assuming $100 \%$ of cells are recovered post-preservation, which is often not the case, using current methodologies appreciably fewer cells can be cryopreserved. This means that some cell culture is required between thawing cells and using them in therapy or HTS campaigns which is not ideal. For instance, one study stored up to $3 \times 10^{6}$ hESCs/cryostraw using a slowfreezing protocol ${ }^{14}$ and significantly fewer hESCs can be preserved by vitrification, although exact numbers can be difficult to ascertain. Human ESCs are vitrified in clumps and, even when the numbers of cells/clump are determined, this can vary considerably from 100 to $400 .{ }^{15,16}$ This makes the literature difficult to compare and presents an obvious disadvantage from a bioprocessing perspective because process monitoring and scheduling require accurate and consistent outputs. Nonetheless, even using bulk methods, Li and colleagues ${ }^{17}$ could only preserve $\sim 120$ clumps of cells per 
cryocontainer, which assuming 400 cells/clump would be $<5 \times 10^{4}$ cells/cryocontainer.

Given the current gap between the numbers of cells required and the capacity of current technologies to preserve hESCs and hESC-derived cells, the focus of this review is the scalability of conventional slow freezing and vitrification. Key barriers which limit the potential for either scale-up or scale-out of these methods are identified and discussed. Furthermore, as scalability is not the only issue that should be considered when choosing a preservation technique, the suitability of lyophilisation to preserve hESCs and their differentiated progeny is also explored.

\section{Why preserve hESCs and their differentiated progeny?}

Human ESCs and hESC-derived cells are preserved for a number of different reasons. Firstly, preservation allows for transport of cells between or across sites. This is critical for storage and distribution facilities such as national stem cell banks and companies with multiple research or manufacturing sites. In addition, it also allows manufacturers of cellular therapies to develop business models where the production is spatially and temporally removed from the clinic.

Secondly, preservation also allows the generation of master and working cell banks such that consistent, quality-controlled (QC), stocks of cells are available for in vitro studies and/or clinical use. For instance, it has been estimated that approximately 150 hESC lines would be required to achieve a sufficient degree of human leukocyte antigen matching to be of benefit to the population, ${ }^{18}$ although this number may be an underestimate. ${ }^{19}$ To continuously culture such a large range of cell lines would be extremely expensive and time consuming. Banking of hESCs is particularly important, as long term continuous culture has been associated with genetic and epigenetic instability. ${ }^{19}$ 
Thirdly, preservation allows for the uncoupling of cell culture from other processes such as differentiation or delivery to patients. Current differentiation protocols are typically complex, lengthy and expensive, therefore, preserving stocks of hESCs allows time for QC testing. This ensures that only high quality, well-characterised hESCs are taken forward through differentiation, thereby reducing waste and process inefficiency. Similarly, it allows for QC and safety testing before cells are delivered to patients and the development of an "off the shelf" business model for these therapies. It also uncouples cell culture from in vitro cell-based assays, such as those used in toxicology studies. In recent years there has been a surge in the use of freshly thawed cells for HTS assays, negating the need for continuous culture of cell lines and thereby cutting down on associated costs and lost time and effort when either cells, equipment or compounds are not ready simultaneously. ${ }^{20,21}$

\section{Current Cryopreservation Methods}

Any preservation technology aims to reliably and consistently maintain the key characteristics of cells. These include; viability, genotype, phenotype and, in the case of hESCs, differentiation potential. An ideal method would be: widely applicable to a range of hESC lines and differentiated cells, scalable such that sufficient cells/container and enough containers/run can be preserved, and generate an output that is easily stored and transported. Working with clinically relevant cells also adds the additional complexity that the process must be compliant with current Good Manufacturing Practice (GMP) guidelines, which limits or avoids the use of xenogeneic components and the use of chemical components which may cause adverse reactions in patients.

As already mentioned, cryopreservation is the most widely used preservation method for mammalian cells, including hESCs and hESC-derived cells. The dangers associated with freezing cells include intracellular ice crystal nucleation and osmotic stresses (depicted in Figure 2), which can result in a loss of cell viability and/or affect cell function. ${ }^{22-25}$ Indeed, ideally the 
formation of intracellular ice should be avoided and intracellular vitrification encouraged. ${ }^{23}$ Therefore, two different freezing methods have been developed which aim to overcome these hurdles through the use of specific freezing rates and cryoprotective agents (CPAs): conventional slow freezing, in which the extracellular solution is frozen but the formation of intracellular ice is minimised, and vitrification, in which the formation of any ice crystals is avoided. These methods are briefly outlined in Figure 3 (for in-depth reviews on aspects of cryobiology, including the role of CPAs and manual ice seeding, please refer to ${ }^{22-26}$ ). In all cases of cryopreservation, cells are recovered by means of a rapid thaw to reduce the risk of developing damaging ice crystals during thawing.

\subsection{Vitrification}

Vitrification is a method by which clumps of cells are placed in a cryoprotective medium and rapidly cooled by plunging samples into liquid nitrogen so that both extracellular and intracellular ice formation is avoided. The glass-phase transition temperature of water is $-138^{\circ} \mathrm{C}$ and vitrification of pure water can only take place at a cooling rate of $10^{6 \circ} \mathrm{C} / \mathrm{sec}$ or above. ${ }^{22}$ Therefore, in order to achieve vitrification of cell clumps at more modest rates, thermal mass is minimised and high concentrations of CPAs ( 4M) are used. 27 The presence of high concentrations of CPAs act to increase the viscosity, decrease rate of nucleation and ice crystal growth and increase the glassphase transition temperature of the solution such that vitrification can occur at achievable cooling rates. ${ }^{22,25}$

Although successfully used to preserve embryos ${ }^{28}$ and hESCs (Section 3.2), vitrification does have its disadvantages. Because rapid cooling rates must be achieved, only small volumes, typically 1-20 $\mu$, may be vitrified, making this an extremely low-throughput process. The high concentrations of CPAs $(\sim 4 \mathrm{M})$, such as dimethylsulfoxide (DMSO), ethylene glycol and 1,2propanediol, used to achieve vitrification can also be highly toxic. ${ }^{27,29}$ Furthermore, CPAs require a step-wise loading protocol ${ }^{29,30}$ to avoid 
exposing the cells to osmotic imbalances, making protocols very labour intensive.

Vitrification protocols which use lower concentrations of CPAs are, however, being developed. Cryostraws or loops are commonly used to vitrify cells and cooling rates of only $\sim 20,000^{\circ} \mathrm{C} / \mathrm{min}$ can be achieved, ${ }^{31}$ necessitating the use of high concentrations of CPAs. Recently, the use of quartz microcapillaries has enabled higher cooling rates $\left(>100,000^{\circ} \mathrm{C} / \mathrm{min}\right.$ ) to be achieved and relatively low concentrations of CPAs (2M 1,2-propandiol and 0.5M trehalose) to be used in the preservation of mouse ESCs. ${ }^{27}$ Furthermore, the use of quartz microcapillaries in combination with cell encapsulation technology, has also enabled the vitrification of mouse mesenchymal stromal cells in even lower concentrations of DMSO $(\sim 1.5 \mathrm{M})$. ${ }^{32}$ Although this does reduce exposure of cells to toxic agents, the need to use small volumes and/or a large surface area remains an absolute requirement in order to enable vitrification at easily achievable cooling rates. Therefore, the potential to scale up the process is still very limited. As will be mentioned in Section 3.2, some "bulk" vitrification methods have been developed through modification of cryocontainers, ${ }^{17,33}$ but even these are limited in the numbers of cells that can be preserved per container.

Instead, the development of protocols that require less manual input would allow for some scale-out of the process and vitrification of larger numbers of cells. One such process is cell encapsulating droplet vitrification whereby cells are encapsulated in small droplets of CPA and injected directly into liquid nitrogen. Tested on a range of mammalian cell types, this method allowed vitrification to occur in relatively low concentrations of CPAs (1.5M propanediol and 0.5M trehalose). ${ }^{34}$ Although multiple step CPA loading and unloading processes were still used, the set-up used could potentially be automated, making it an attractive option for larger scale vitrification of cells.

\subsection{Vitrification of hESCs}


Human ESCs grown in colonies, as opposed to monolayers, have typically been vitrified using an OPS technique as outlined in Figure 4. High levels of cell recovery $(>75 \%)$ have been recorded using this protocol, particularly when compared with some of the early attempts at preserving hESCs using slow freezing, ${ }^{15,16,35}$ making this a popular choice. In addition, in order to overcome the issues of sterility in such an open system and make it more GMP compatible, closed vitrification protocols have been developed. ${ }^{16}$

Although vitrified hESCs retain their ability to grow as colonies and differentiate upon thawing, the major drawback of using this method is the small number of cells that can be preserved per cryocontainer. For example, Li et al vitrified 5-7 clumps, each containing 100-200 cells, per cryostraw, giving a maximum of 1400 cell per straw. ${ }^{15}$ As mentioned in Section 3.1, the development of simpler, less labour intensive and time consuming protocols may allow for the vitrification of larger numbers of cells per run. One such protocol involves the enzymatic dissociation of hESC colonies into clumps, transfer of cells into a single vitrification medium, and further transfer of the cells into a cryovial which is then immediately plunged into liquid nitrogen. Unfortunately, poor recovery rates of only $12 \%{ }^{36}$ and $\sim 20 \%{ }^{37}$ currently make this method nonviable without a great deal of optimisation.

More recently, a cell strainer has been used to vitrify hESCs colonies as this could hold a large number of clumps at once whilst retaining a rapid cooling rate once plunged into liquid nitrogen. ${ }^{33}$ Although cells were successfully preserved, with high survival rates and retention of pluripotency, this new carrier was bulky and irregular in shape making it hard to manipulate and store. Since then, $\mathrm{Li}$ and colleagues have devised an alternative cryocontainer, which is based on a $1 \mathrm{ml}$ cryovial modified to contain a cell strainer, to overcome this. ${ }^{17}$ Using this modified vial these workers were able to preserve 20 times more hESC clumps per straw than in the OPS method. Nonetheless, assuming a maximum of 400 cells/clump (based on numbers in $\left.{ }^{16}\right)$, this amounts to $<5 \times 10^{4}$ cells/cryocontainer, compared to the $9 \times 10^{6}$ cells required for a HTS campaign. ${ }^{5}$ Furthermore, the system currently requires in 
house' adaptation of a commercially available cryovial which is not ideal from a bioprocess perspective.

It is clear that even these so-called "bulk" or simplified methods are unable to preserve significant numbers of cells successfully and that they are not a true scale-up solution. Similarly, even if the process could be automated, there still remains the issue of small numbers of cells per cryocontainer. This would entail thawing numerous containers for any single application which is again labour intensive, and the need to maintain discrete batches for particular applications could lead to a significant amount of waste if batch size is not carefully controlled. Thus, it remains questionable whether enough hESCs could ever be vitrified successfully to be used in cell therapies or in in vitro assays without the need for some culturing post-thaw.

It is also notable that vitrification of hESCs has so far focussed on preserving fragments or clumps of hESC colonies. The preservation and culture of cells in colonies is incompatible with general bioprocessing requirements due to their inherent heterogeneity and variability in size. Human ESC propagation in monolayer, rather than colony culture facilitates cell processing and is therefore likely to become the standard for hESCs unless suspension or microcarrier culture can be achieved at a suitable scale. Hence it is paramount that preservation strategies are compatible with this type of culture, where cells are enzymatically dissociated to single cells or small clumps of 2-3 cells. To the author's best knowledge, vitrification of suspended hESCs has not yet been reported. However, methods such as the encapsulating droplet vitrification technique mentioned in Section 3.1, ${ }^{34}$ which has been demonstrated to preserve post-thaw viability of mouse ESCs, show promise if they can be made GMP compatible.

\subsection{Conventional slow freezing}

Conventional slow freezing, or controlled-rate freezing, involves cooling the cells at approximately $1^{\circ} \mathrm{C} / \mathrm{min}$, most commonly in $1 \mathrm{ml}$ polypropylene 
cryovials, in a cryoprotective medium containing foetal bovine serum (FBS) and/or growth medium in addition to a CPA (typically $5-10 \% \mathrm{v} / \mathrm{v}$ ). It is noteworthy that, reflecting the general trend within biopharmaceutical industries, commercial cryopreservation media are now available which do not include FBS. This strategy enables the same level of protection for the cells, without the associated risks of using FBS, such as the potential for contamination with a transmissible spongiform encephalopathy and lot-lot variability. Although every cell type, due to differences in membrane permeability, surface area and water content, potentially has a different ideal cooling rate, ${ }^{22,24} 1^{\circ} \mathrm{C} / \mathrm{min}$ is generally appropriate and can be achieved in a low-tech fashion using a freezing container (e.g. "Mr. Frosty" manufactured by Nalgene) or using a controlled-rate freezer. Prior to cooling (Fig. 3), ice nucleation should be deliberately initiated such that extracellular ice formation can occur in a controlled manner, particularly when preserving stress sensitive cells.

A number of different compounds can serve as CPAs in slow freezing, including sugars such as trehalose and sucrose, but DMSO is the most widely used one. In this method, CPAs that can penetrate the cell (e.g. DMSO) are used to reduce the freezing point of the intracellular solution and cell shrinkage, such that the desired intracellular vitrification can be achieved before intracellular ice forms. ${ }^{22,23}$ Although relatively low concentrations of CPAs are used (typically $<1.5 \mathrm{M}$ ), most, including DMSO, are still toxic to cells, particularly at temperatures above $0^{\circ} \mathrm{C}^{23,30}$ and thus exposure at room temperature must be limited. This is achieved by rapidly commencing the freezing process before preservation and diluting out the CPAs from the cell mixture upon thawing. Step-wise loading protocols can also be used to minimise osmotic shock to the cells.

On a laboratory scale, $1-10 \times 10^{6}$ cells in $1 \mathrm{ml}$ of cryopreservation medium in a 1-2 $\mathrm{ml}$ polypropylene cryovial are commonly frozen and stored using the slow freezing method. ${ }^{38}$ In order to cryopreserve larger quantities of cells, scaleout methods could be considered. For instance, automation of vial filling and capping, using systems such as the "Fill-It" (TAP Biosystems, Royston, UK) 
can be used to increase the quantities of vials prepared, whilst ensuring cells are not exposed to potentially toxic CPAs for an extended period of time.

Alternatively, a scale-up approach could be used by increasing the density of cells/ml frozen and/or increasing the size of cryocontainer. However, this strategy would represent particular technical challenges. These include ensuring sufficiently high rates of heat transfer from the larger liquid volumes and high mass transfer of CPAs into the larger cell numbers. One option is to use cryobags rather than large vials. Typically used for blood banking, these have a large surface to volume ratio and therefore facilitate the removal of latent heat from the cells during the cooling process, making them more suitable for larger scale freezing than vials. Indeed, studies have shown that significantly more than $10^{6}$ cells at a time can be frozen by slow freezing methods using such bags. For example, $50-100 \mathrm{ml}$ of $20-50 \times 10^{6}$ Chinese Hamster Ovary (CHO)-S cells/ml were successfully cryopreserved in $250 \mathrm{ml}$ bags. ${ }^{38,39}$ However, cryobags have been known to fail ${ }^{40}$ and it is important to consider the logistics of generating cell banks or doses of cellular therapies using these. In one study $17 \times 10^{6}$ Baby Hamster Kidney (BHK) cells/ml were successfully preserved in $100 \mathrm{ml}$ cryobags using a peristaltic pump to fill the bags at $100 \mathrm{ml} / \mathrm{min}$ and it was found that a 1.5 hour window existed in which to bank cells, using DMSO as a CPA. ${ }^{41}$ Furthermore, bag handling can also be automated using systems such as the BioArchive ${ }^{\circledR}$ System (ThermoGenesis Corp, CA, USA), indicating that using such bags for scale up of the slow freezing process is now possible.

\subsection{Conventional slow freezing of hESCs}

Although mouse ESCs can be successfully preserved by slow freezing, several studies have shown poor survival and recovery rates of hESC colonies or clumps when frozen using this protocol, quoting rates between 0 30\%. ${ }^{12,15,16,42}$ For instance, in a comparative study, Li and colleagues ${ }^{15}$ found that no hESC clumps preserved by conventional slow freezing recovered post-thaw whereas $89 \%$ of vitrified cells did. Clumps of cells 
preserved in this manner are typically $>70 \mu \mathrm{m}$ in diameter ${ }^{15}$ and recently, it was suggested that the poor recovery noted is likely due to reduced cryoprotectant exposure of cells in the centre of the clumps leading to cell death during slow freezing. ${ }^{43}$

Nonetheless, some studies have reported successful slow freezing of hESC colonies. ${ }^{12,44-46}$ For instance, when freezing conditions were partially optimised (details of which can be found in the original report), an approximately $80 \%$ survival rate of the $\mathrm{H} 1$ hES cell line could be achieved. ${ }^{45}$ However, there was significant variation between runs (15\%), indicating that benefits could be gained from further optimisation. One of the critical factors in attaining high hESC survival identified in this study was the inclusion of an ice seeding step at -7 to $-10^{\circ} \mathrm{C}$. ${ }^{45}$ Although more systematic studies are needed which explore the role of ice seeding, and other cryobiological factors, on slow freezing of hESCs, this is consistent with other studies. 15,47 Furthermore, another study ${ }^{46}$ has demonstrated the variability in cell survival between hES cell lines using a slow freezing method, highlighting that it is key to test any process on a number of lines with different provenances. Notably though, Crook and colleagues ${ }^{14}$ used a slow freezing technique to bank 6 clinical grade hES cell lines. Although the authors do not comment on the recovery of cells post-thaw as this was not the main focus of the work, relatively large numbers of cells were frozen in this manner: 40-60 straws with $3 \times 10^{6}$ cells/straw (in $200 \mu \mathrm{l}$ media), underlining the potential advantage of this technique over vitrification in terms of how many cells can be preserved at once.

Ideally, in order to avoid potential mass transfer issues through cell clumps, hESCs would need to be frozen in a single cell suspension, as other mammalian cells frequently are. However, hESCs are typically passaged and frozen as colonies because single cells are susceptible to dissociationinduced apoptosis. ${ }^{48}$ In fact, Richards and colleagues ${ }^{16}$ speculated that the poor survival rates following conventional slow freezing of hESC clumps was due to ice crystal formation during the process disrupting cell adhesion. However, Watanabe et al. ${ }^{48}$ demonstrated that dissociating cells in the 
presence of a small molecule Rho-kinase inhibitor (Y27632) significantly improved cell survival by protecting cells against apoptosis. More recently a number of different studies have shown that using this inhibitor in both the freezing and thawing media increased hESC survival rate, reduced recovery time and increased subsequent colony formation compared to controls when cells were dissociated to the single cell level. ${ }^{43,49-52}$ Although not specified in every study, $1-2 \times 10^{6}$ cells/cryocontainer were typically preserved in this manner. ${ }^{50,52}$ A number of Rho-kinase inhibitors exist and continue to be tested for their effects on hESCs ${ }^{53}$ and the mechanism of action of Y27632 is still debated. ${ }^{43,48,54}$ Nonetheless, Y27632 is still the most commonly used anti-apoptotic agent at the moment. It remains to be seen whether alternative compounds, such as caspase inhibitors, ${ }^{55}$ become more widely used in the future.

In addition to slow freezing hESCs in suspension, either as clumps or as single cells, cryopreservation of hESCs in situ on tissue culture plates, ${ }^{56}$ cassettes ${ }^{57}$ and microcarriers ${ }^{58}$ has recently been reported. Cryopreserving hESCs embedded between two layers of the extracellular matrix substitute Matrigel on tissue culture plates, significantly increased the viability of colonies compared to those frozen in suspension and those preserved on a single layer of Matrigel. ${ }^{56}$ Similarly, Amps et al. ${ }^{57}$ showed poor survival and recovery of hESC colonies when cryopreserved in feeder cell layer coated $T$ flasks. However, these workers had greater success cryopreserving hESC colonies in tissue culture cassettes (Clinicell cassettes from Mabio International, France). Following freezing and thawing more than 100 colonies adhered, as compared with 0-3 colonies in the tissue culture flasks, and high levels of pluripotency markers were retained.

Preserving cells in situ enables the maintenance of cell-cell connections and abolishes the need for certain processing steps such as dissociation of the cells from the surface, although it is not particularly scalable. This is due to the cost of freezing medium to cover such large surface areas and the space required to store $T$ flasks, plates or cassettes when compared with vials. Work also needs to be done to optimise the cooling rates achievable in such 
systems but it nonetheless presents an interesting opportunity to generate frozen plates of assay ready cells for use in in vitro assays such as toxicology studies.

The past five years or so has seen a number of studies developing methods for culturing hESCs on microcarriers. ${ }^{59-66}$ These provide a much larger surface area to volume ratio for not only growth but, potentially, also cryopreservation. Indeed, Nie et al. ${ }^{58}$ demonstrated that preserving hESCs on the microcarriers they were grown on resulted in a higher recovery of undifferentiated cells compared to cells preserved in suspension. Microcarriers are available in a variety of porosities that can enable or restrict the penetration of cells into the carrier. Notably, the microcarriers used by Nie and colleagues were microporous, meaning that cells only grew in colonies on the outer surface of the carrier and thus were not subject to any mass transfer issues such as nutrient or cryoprotectant diffusion. Although they only preserved $10^{6}$ cells $/ \mathrm{ml}$ in cryovials, the number of cells preserved could hopefully be increased with some optimisation. From a bioprocessing perspective, this is an interesting advance because it would reduce the number of processing steps, and hence, time. The added advantage of this technique would also be that successful differentiation of hESC on microcarriers to endoderm ${ }^{60}$ and cardiomyocytes ${ }^{67}$ has been reported. Therefore cells could be grown, preserved, thawed and then differentiated on microcarriers, further cutting down on processing steps.

Given the precedent with other mammalian cell lines such as the $\mathrm{CHO}-\mathrm{S}$ used in the biopharmaceutical industry, ${ }^{38}$ there is great potential for large numbers of hESCs to be cryopreserved at once through slow freezing. However, this has yet to be reported and it remains to be seen whether it can be achieved whilst maintaining the key characteristics of these cells. Notably, much of the work discussed here, including that on the use of ROCK inhibitors, has focussed on growth of hESCs in colonies. However, single cell propagation and/or passaging would facilitate and improve not just cryopreservation but cell processing in general. Work is ongoing in this area but it has already been reported that hESCs can be grown in monolayers ${ }^{7-9}$ or aggregate 
suspension, ${ }^{68-71}$ with enzymatic treatment used to dissociate cells into small clumps. Such small clumps should be more amenable to slow freezing, allowing large quantities of hESCs to be preserved at once, but little has been reported on the cryopreservation of cells grown in monolayer or suspension. For example, Priddle and colleagues ${ }^{8}$ reported that a conventional slow freezing protocol, without the inclusion of a Rho-kinase inhibitor, was used to preserve cells grown in monolayers but there was no mention of post-thaw recovery rates.

\subsection{Cryopreservation of hESC-derived cells}

Current work on hESC differentiation into clinical and research relevant cells is generally focused on either the development of differentiation protocols or improving the efficiency of existing protocols. However, some reports are emerging which look at whether hESC-derived cells can be cryopreserved using slow freezing or vitrification.

For example, human ESC-derived neurons have been successfully cryopreserved using a slow freezing technique. ${ }^{72}$ By exposing cells to a caspase inhibitor, which aims to prevent apoptosis, recovery rates of up to 83\% could be achieved. Consistent with literature on hESCs, Norström et al. 55 were able to successfully slow freeze single cell suspensions, but not clusters, of cardiomyocytes. Clumps of cardiomyocytes could, however, be preserved by using a sealed straw vitrification method. Unfortunately, in their article the authors did not specify what recovery rates were obtained. Another study revealed that when during the differentiation protocol hESC-derived cardiomyocytes were cryopreserved had a significant impact on the recovery of cell function. ${ }^{73}$ Furthermore, they also noted that the beating frequency of cardiomyocyte clusters post-thaw was higher than that of non frozen clusters, highlighting some of the physiological changes that may occur in cells as a result of cryopreservation. It is clear that simple cell survival assays are not sufficient and that in depth analysis of cellular function post-thaw should be 
carried out in all studies, particularly if these cells are to be used as therapeutic agents.

Given the likely future impact of hESC-derived cells on healthcare as either cellular therapies themselves or in drug screening assays, it is particularly important that robust and consistent methods for preserving these cells are developed. Again, the scalability of such methods will be critical, particularly as some reports emerge on the expansion of hESC-derived cells and not just the differentiation protocols themselves (for example ${ }^{74,75}$ ). Thus, it is promising to see that in a study using a mixed cell population which included 25-59\% hESC-derived cardiomyocytes, $4-8 \times 10^{7}$ cells per $1.5 \mathrm{ml}$ cryovial could be preserved using a slow freezing protocol. ${ }^{76}$ Recovery rates of $\sim 75 \%$ were achieved, a promising indication that large scale preservation of hESCderived cells is feasible. However, in light of some of the physiological changes in hESC-derived cardiomyocytes noted by Kim and colleagues postthaw, much optimisation of such protocols may still be needed. It also remains to be seen whether hESC-derived cells can be frozen successfully in assay-ready plates in order to cut down on processing time if these cells are to be used in, for instance, toxicology studies.

\section{Dry preservation: a potential alternative to cryopreservation}

Whilst the use of slow freezing for the preservation of hESCs and their differentiated progeny shows the potential to be scalable, there are issues with this technique that are not related to scale and have therefore not been discussed here. For example, although DMSO is commonly used as a cryoprotectant, even in GMP-compatible solutions such as CryoStor (BioLife Solutions Inc, WA, USA), it is toxic to cells ${ }^{23,29}$ and can cause adverse reactions in patients. ${ }^{77}$ Transport of vitrified cells can also be very expensive as dry shippers, which hold samples at $-150^{\circ} \mathrm{C}$ without the risks associated with transporting liquid nitrogen, are required to prevent any partial thawing of the cells. Thus, it is important to consider whether a preservation method, 
such as dry preservation, which avoids the use of DMSO and results in a product that can be maintained at room temperature, would be suitable.

Dehydrating cells in a controlled manner avoids low temperature storage altogether. Generally, drying cells leads to membrane damage, protein denaturation and subsequent cell death but the natural ability of some organisms such as yeast cells and fungal spores to survive almost complete dehydration ${ }^{78}$ suggests 'safe' dehydration and rehydration of mammalian cells should be possible. If feasible this would be both economically and practically advantageous compared to cold storage and transport as dried formulations could be stored at room temperature, although care that conditions remain stable needs to be taken. There is also a precedent, with lyophilisation of pharmaceutical-grade products occurring at a large scale, although its acceptance within the cell biology community may be more difficult.

Freeze drying, or lyophilisation, is typically used to preserve bacterial cells and fungi and involves vacuum desiccation. Briefly, there are three stages: freezing in order to partly crystallise the solvent so that it can be separated from the solutes, sublimation of the resultant ice (primary drying phase) and finally, a secondary drying phase where the majority of the remaining moisture is removed by desorption. ${ }^{78}$ Cells can be pre-treated with a lyoprotectant such as disaccharide sugars but nonetheless, the process can be damaging. 78,79

Efforts to lyophilise mammalian cells have largely focused on trying to generate freeze-dried blood, with some studies showing that erythrocytes and platelets can be successfully lyophilised, stored and rehydrated, although the processes are not yet optimal. ${ }^{78,80}$ Although the genomic material of mouse ES cells and spermatozoa has been preserved following freeze-drying, ${ }^{81}$ it was not until recently that successful lyophilisation, storage for one week, and rehydration of nucleated cells was reported. ${ }^{82}$ The authors demonstrated viability of mononuclear cells isolated from human umbilical cord blood following rehydration, with similar levels of $\mathrm{CD} 34^{+}$haematopoietic stem cells 
present in the population before and after preservation, which were capable of differentiating into a number of cell types. Although it remains to be seen whether lyophilised hESCs would retain their characteristics, this technique represents an interesting alternative to cryopreservation and should be explored.

Cells can also simply be dried under vacuum for example, without the need for freezing. As with lyophilisation, the introduction of a disaccharide such as trehalose, or a combination of trehalose and glycerol, into the cells offers protection from desiccation. ${ }^{83}$ It has been shown that human mesenchymal stem cells exposed to trehalose and glycerol can be successfully dehydrated under vacuum and stored for 1 day. ${ }^{84}$ Upon rehydration they regained their normal morphology and adhesive capability, were $>90 \%$ viable, proliferated and maintained expression of key surface markers. However, the authors did admit that there was a large amount of inconsistency from trial to trial and that longer storage times would need to be achieved, again underlining the need for these techniques to be improved and optimised.

Furthermore, based on their findings in human foreskin fibroblasts, Puhlev and colleagues ${ }^{83}$ suggested that free-radical mediated damage may occur within desiccated cells. Thus there is a need for a variety of post-preservation assays to be carried out, beyond the simple viability tests to ascertain that cells have not been damaged or altered in any manner. This will be particularly true of hESCs and their derivatives if they are to be used in the clinic.

Notably, one the biggest hurdles to successful lyophilisation or dehydration of cells is delivering the protective agents, such as the disaccharide trehalose, into cells as both their intracellular and extracellular presence is required for maximum effect. Trehalose is a hydrophilic compound and therefore nonpermeating but an intracellular concentration of $\geq 100 \mathrm{mM}$ is required for effective cell protection. ${ }^{85,86}$ A number of different techniques have been used to deliver trehalose into cells including thermal shock, ${ }^{83}$ induction of trehalose synthesis in cells by genetic engineering ${ }^{87}$ and induction of pore 
formation using mutant bacterial toxins. ${ }^{88}$ However, these techniques typically do not achieve a high enough intracellular concentration of trehalose, can be cytotoxic and/or represent safety concerns if the treated cells are subsequently to be used as therapies. Novel cell loading techniques are therefore being developed. For instance, unilamellar liposomes containing trehalose have been used to deliver this disaccharide into erythrocytes. Transfer of trehalose is believed to occur through both adsorption of the lipid vesicles to the erythrocyte membrane and also membrane fusion. ${ }^{89}$ The generation of trehalose-containing, thermally-responsive, nanocapsules has enabled up to $300 \mathrm{mM}$ trehalose to be loaded into 3 T3 fibroblasts through absorptive endocytosis. ${ }^{86}$ However, a cold shock step was used to release trehalose from the nanocapsules intracellularly and it remains to be seen how hESCs would be affected by such treatment. Another approach has been to use a biopolymer (poly(L-lysine iso-phtalamide) backbone with Lphenylalanine attached) to increase membrane permeability of cells to trehalose. ${ }^{85}$ The authors reported a significant increase in trehalose loaded into erythrocytes using this biopolymer, when compared to cells treated with poly( (-lysine iso-phtalamide) and trehalose or trehalose alone.

Overall, this work is encouraging and suggests that although much work would need to be done to optimise protocols for use with hESCs or hESCderived cells, dry preservation represents a potential alternative for hESC preservation. It would be a particularly attractive option for longer-term banking.

\section{Conclusions}

The recent start of some long-awaited clinical trials using hESC-derived cells in both the UK and USA highlights the potential use of these cells as therapeutic agents. Furthermore, as methods by which to produce these cells reproducibly at scale continue to be developed, their use in drug screening and toxicology assays is also set to increase. With $10^{6}-10^{9}$ cells typically being required per patient ${ }^{13}$ and an even larger number of cells required for a 
single HTS campaign, ${ }^{5}$ it is important that scalable techniques to preserve these cells and hESCs themselves are developed. Currently, hESCs and their differentiated progeny are either vitrified or preserved by slow freezing: cryopreserved hESCs can be obtained from cell banks, cryopreserved hESCderived cardiomyocytes are available commercially for use in in vitro assays and Geron's hESC-derived oligodendrocyte progenitor cells (GRNOPC1), which are currently undergoing clinical trials, are also supplied as a cryopreserved formulation.

Although vitrification of hESCs can lead to high cell recovery rates, it remains an inefficient process, requires a skilled operator and can only preserve very small quantities of cells. Unfortunately, because of the inherent nature of vitrification, true scale-up is not an option. Process automation would relieve some of the burden, allowing larger numbers of cryocontainers to be processed, but would not overcome the inherent problem that each container can only hold limited volumes.

Mixed results using slow freezing to preserve hESCs have been reported. However, this method is much more scalable than vitrification, as shown by the ability to preserve large numbers of, for example, CHO-S cells. ${ }^{38}$ Slow freezing is also more suited to preservation of cells in single cell suspension than in colonies, which is compatible with recent developments in hESC culture processes. However, whether hESCs grown in monolayers or suspension cultures can be successfully cryopreserved (with or without the use of ROCK inhibitors), has yet to be published.

Although optimisation for use with hESCs and their differentiated progeny is undoubtedly required to retain maximum cell function, be GMP compliant and so forth, the scalability of slow freezing protocols means that it is likely to become the cryopreservation method of choice in the coming years. It will allow large numbers of cells to be frozen and stored at once if existing technologies such as cryobags and bag handling systems are exploited. Nonetheless, as highlighted in this review, alternatives to cryopreservation, such as lyophilisation, do exist and should also be explored. 


\section{Acknowledgments}

The author would like to thank Dr. A Want (Loughborough University) for his advice in the generation of this manuscript.

Abbreviations: $\mathrm{CHO}$, Chinese Hamster Ovary; CPA, cryoprotective agent; DMSO, dimethylsulfoxide; FBS, foetal bovine serum; GMP, Good Manufacturing Practice; hESC, human embryonic stem cell; HTS, highthroughput screen; MCB, master cell bank; OPS, open pulled straw; QC, quality-controlled; WCB, working cell bank. 


\section{Literature Cited}

1. Barker C, Culme-Seymour E, Dalton S, Hayek A, Genbacev O. The Year in Regenerative Medicine. Regen Med. 2011;6:21-30.

2. Friedrich Ben-Nun I, Benvenisty N. Human embryonic stem cells as a cellular model for human disorders. Mol Cell Endocrinol. 2006;252:154-159.

3. Ameen C, Strehl R, Bjorquist P, Lindahl A, Hyllner J, Sartipy P. Human embryonic stem cells: current technologies and emerging industrial applications. Crit Rev Oncol Hematol. 2008;65:54-80.

4. Sartipy P, Bjorquist P, Strehl R, Hyllner J. The application of human embryonic stem cell technologies to drug discovery. Drug Discov Today. 2007;12:688-699.

5. Desbordes SC, Placantonakis DG, Ciro A, Socci ND, Lee G, Djaballah H, Studer L. High-throughput screening assay for the identification of compounds regulating self-renewal and differentiation in human embryonic stem cells. Cell Stem Cell. 2008;2:602-612.

6. Braam SR, Tertoolen L, van de Stolpe A, Meyer T, Passier R, Mummery CL. Prediction of drug-induced cardiotoxicity using human embryonic stem cell-derived cardiomyocytes. Stem Cell Res. 2010;4:107-116. 
7. Thomas RJ, Anderson D, Chandra A, Smith NM, Young LE, Williams D, Denning C. Automated, scalable culture of human embryonic stem cells in feeder-free conditions. Biotechnol Bioeng. 2009;102:1636-1644.

8. Priddle H, Allegrucci C, Burridge P, Munoz M, Smith NM, Devlin L, Sjoblom C, Chamberlain S, Watson S, Young LE, Denning C. Derivation and characterisation of the human embryonic stem cell lines, NOTT1 and NOTT2. In Vitro Cell Dev Biol Anim. 2010;46:367-375.

9. Mahlstedt MM, Anderson D, Sharp JS, McGilvray R, Munoz MD, Buttery LD, Alexander MR, Rose FR, Denning C. Maintenance of pluripotency in human embryonic stem cells cultured on a synthetic substrate in conditioned medium. Biotechnol Bioeng. 2010;105:130-140.

10. Rodin S, Domogatskaya A, Strom S, Hansson EM, Chien KR, Inzunza J, Hovatta O, Tryggvason K. Long-term self-renewal of human pluripotent stem cells on human recombinant laminin-511. Nat Biotechnol. 2010;28:611-615.

11. Mummery CL. Cardiology: solace for the broken-hearted? Nature. 2005; 433:585-587.

12. Hunt CJ,Timmons PM. Cryopreservation of human embryonic stem cell lines. Methods Mol Biol. 2007;368:261-270. 
13. Mason C, Dunnill P. Quantities of cells used for regenerative medicine and some implications for clinicians and bioprocessors. Regen Med. 2009;4:153-157.

14. Crook JM, Peura TT, Kravets L, Bosman AG, Buzzard JJ, Horne R, Hentze H, Dunn NR, Zweigerdt R, Chua F, Upshall A, Colman A. The generation of six clinical-grade human embryonic stem cell lines. Cell Stem Cell. 2007;1:490-494.

15. Li Y, Tan JC, Li LS. Comparison of three methods for cryopreservation of human embryonic stem cells. Fertil Steril. 2010;93:999-1005.

16. Richards M, Fong CY, Tan S, Chan WK, Bongso A. An efficient and safe xeno-free cryopreservation method for the storage of human embryonic stem cells. Stem Cells. 2004;22:779-789.

17. Li T, Mai Q, Gao J, Zhou C. Cryopreservation of human embryonic stem cells with a new bulk vitrification method. Biol Reprod. 2010;82:848-853.

18. Taylor CJ, Bolton EM, Pocock S, Sharples LD, Pedersen RA, Bradley JA. Banking on human embryonic stem cells: estimating the number of donor cell lines needed for HLA matching. Lancet. 2005;366:2019-2025.

19. Allegrucci C, Young LE. Differences between human embryonic stem cell lines. Hum Reprod Update. 2007;13:103-120. 
20. Zaman GJ, de Roos JA, Blomenrohr M, van Koppen CJ, Oosterom J. Cryopreserved cells facilitate cell-based drug discovery. Drug Discov Today. $2007 ; 12: 521-526$.

21. Wigglesworth MJ, Lawless KJ, Standing DJ, Mackenzie EK, Kitchen VR, McKay F, Ward E, Brough SJ, Stylianou M, Jewitt FR, McLaren-Douglas AM, Jowet MI, Tamayama N, Finnigan D, Ding J, Wise A. Use of cryopreserved cells for enabling greater flexibility in compound profiling. J Biomol Screen. 2008;13:354-362.

22. Fowler A, Toner M. Cryo-injury and biopreservation. Ann N Y Acad Sci 2005;1066:119-135.

23. Meryman HT. Cryopreservation of living cells: principles and practice. Transfusion. 2007;47:935-945.

24. Mazur P. Freezing of living cells: mechanisms and implications. Am J Physiol. 1984;247:C125-42.

25. Karlsson JO, Toner M. Long-term storage of tissues by cryopreservation: critical issues. Biomaterials. 1996;17:243-256.

26. Hubel A. Parameters of cell freezing: implications for the cryopreservation of stem cells. Transfus Med Rev. 1997;11:224-233. 
27. He X, Park EY, Fowler A, Yarmush ML, Toner M. Vitrification by ultra-fast cooling at a low concentration of cryoprotectants in a quartz microcapillary: a study using murine embryonic stem cells. Cryobiology. 2008;56:223-232.

28. Makarevich AV, Kubovicova E, Popelkova M, Fabian D, Cikos S, Pivko J, Chrenek P. Several aspects of animal embryo cryopreservation: anti-freeze protein (AFP) as a potential cryoprotectant. Zygote. 2010;18:145-153.

29. Fahy GM. Cryoprotectant toxicity neutralization. Cryobiology. 2010;60:S45-53.

30. Paynter SJ. Principles and practical issues for cryopreservation of nerve cells. Brain Res Bull. 2008;75:1-14.

31. He X. Preservation of Embryonic Stem Cells, In: Atwood C (Ed): Methodological Advances in the Culture, Manipulation and Utilization of Embryonic Stem Cells for Basic and Practical Applications. InTech, 2011;113138.

32. Zhang W, Yang G, Zhang A, Xu LX, He X. Preferential vitrification of water in small alginate microcapsules significantly augments cell cryopreservation by vitrification. Biomed Microdevices. 2010;12: 89-96. 
33. Li T, Zhou C, Liu C, Mai Q, Zhuang G. Bulk vitrification of human embryonic stem cells. Hum Reprod. 2008;23:358-364.

34. Demirci U, Montesano G. Cell encapsulating droplet vitrification. Lab Chip $2007 ; 7: 1428-1433$.

35. Reubinoff BE, Pera MF, Vajta G, Trounson AO. Effective cryopreservation of human embryonic stem cells by the open pulled straw vitrification method. Hum Reprod. 2001;16:2187-2194.

36. Fujioka T, Yasuchika K, Nakamura Y, Nakatsuji N, Suemori H. A simple and efficient cryopreservation method for primate embryonic stem cells. Int $\mathrm{J}$ Dev Biol. 2004;48:1149-1154.

37. Suemori H, Yasuchika K, Hasegawa K, Fujioka T, Tsuneyoshi N, Nakatsuji N. Efficient establishment of human embryonic stem cell lines and long-term maintenance with stable karyotype by enzymatic bulk passage. Biochem Biophys Res Commun. 2006;345:926-932.

38. Kleman MI, Oellers K, Lullau E. Optimal conditions for freezing CHO-S and HEK293-EBNA cell lines: influence of Me2SO, freeze density, and PEImediated transfection on revitalization and growth of cells, and expression of recombinant protein. Biotechnol Bioeng. 2008;100:911-922. 
39. Heidemann R, Mered M, Wang DQ, Gardner B, Zhang C, Michaels J, Henzler HJ, Abbas N, Konstantinov K. A new seed-train expansion method for recombinant mammalian cell lines. Cytotechnology. 2002;38:99-108.

40. Khuu HM, Cowley H, David-Ocampo V, Carter CS, Kasten-Sportes C, Wayne AS, Solomon SR, Bishop MR, Childs RM, Read EJ. Catastrophic failures of freezing bags for cellular therapy products: description, cause, and consequences. Cytotherapy. 2002;4:539-549.

41. Heidemann R, Lunse S, Tran D, Zhang C. Characterization of cell-banking parameters for the cryopreservation of mammalian cell lines in $100-\mathrm{mL}$ cryobags. Biotechnol Prog. 2010;26:1154-1163.

42. Xu X, Cowley S, Flaim CJ, James W, Seymour L, Cui Z. The roles of apoptotic pathways in the low recovery rate after cryopreservation of dissociated human embryonic stem cells. Biotechnol Prog. 2010;26:827-837.

43. Li X, Krawetz R, Liu S, Meng G, Rancourt DE. ROCK inhibitor improves survival of cryopreserved serum/feeder-free single human embryonic stem cells. Hum Reprod 2009;24:580-589.

44. Holm F, Strom S, Inzunza J, Baker D, Stromberg AM, Rozell B, Feki A, Bergstrom R, Hovatta O. An effective serum- and xeno-free chemically defined freezing procedure for human embryonic and induced pluripotent stem cells. Hum Reprod. 2010;25:1271-1279. 
45. Ware CB, Nelson AM, Blau CA. Controlled-rate freezing of human ES cells. BioTechniques. 2005;38:879-883.

46. Valbuena D, Sanchez-Luengo S, Galan A, Sanchez E, Gomez E, Poo ME, Ruiz V, Genbacev O, Krtolica A, Pellicer A, Moreno R, Simon C. Efficient method for slow cryopreservation of human embryonic stem cells in xeno-free conditions. Reprod Biomed Online. 2008;17:127-135.

47. Lee JY, Lee JE, Kim DK, Yoon TK, Chung HM, Lee DR. High concentration of synthetic serum, stepwise equilibration and slow cooling as an efficient technique for large-scale cryopreservation of human embryonic stem cells. Fertil Steril. 2010;93:976-985.

48. Watanabe K, Ueno M, Kamiya D, Nishiyama A, Matsumura M, Wataya T, Takahashi JB, Nishikawa S, Nishikawa S, Muguruma K, Sasai Y. A ROCK inhibitor permits survival of dissociated human embryonic stem cells. Nat Biotechnol. 2007;25:681-686.

49. Claassen DA, Desler MM, Rizzino A. ROCK inhibition enhances the recovery and growth of cryopreserved human embryonic stem cells and human induced pluripotent stem cells. Mol Reprod Dev. 2009;76:722-732.

50. Mollamohammadi S, Taei A, Pakzad M, Totonchi M, Seifinejad A, Masoudi N, Baharvand $\mathrm{H}$. A simple and efficient cryopreservation method for 
feeder-free dissociated human induced pluripotent stem cells and human embryonic stem cells. Hum Reprod. 2009;24:2468-2476.

51. Martin-Ibaňez R, Unger C, Strömberg A, Baker D, Canals J, Hovatta O. Novel cryopreservation method for dissociated human embryonic stem cells in the presence of a ROCK inhibitor. Hum Reprod. 2008;23:2744-2754.

52. Xu X, Cowley S, Flaim CJ, James W, Seymour LW, Cui Z. Enhancement of cell recovery for dissociated human embryonic stem cells after cryopreservation. Biotechnol Prog. 2010;26:781-788.

53. Andrews PD, Becroft M, Aspegren A, Gilmour J, James MJ, McRae S, Kime R, Allcock RW, Abraham A, Jiang Z, Strehl R, Mountford JC, Milligan G, Houslay MD, Adams DR, Frearson JA. High-content screening of feeder-free human embryonic stem cells to identify pro-survival small molecules. Biochem J. 2010;432:21-33.

54. Krawetz RJ, Li X, Rancourt DE. Human embryonic stem cells: caught between a ROCK inhibitor and a hard place. Bioessays. 2009;31:336-343.

55. Norström A, Akesson K, Hardarson T, Hamberger L, Bjorquist P, Sartipy P. Molecular and pharmacological properties of human embryonic stem cellderived cardiomyocytes. Exp Biol Med. 2006;231:1753-1762. 
56. Ji L, de Pablo JJ, Palecek SP. Cryopreservation of adherent human embryonic stem cells. Biotechnol Bioeng. 2004;88:299-312.

57. Amps KJ, Jones M, Baker D, Moore HD. In situ cryopreservation of human embryonic stem cells in gas-permeable membrane culture cassettes for high post-thaw yield and good manufacturing practice. Cryobiology. 2010;60:344-350.

58. Nie Y, BergendahI V, Hei DJ, Jones JM, Palecek SP. Scalable culture and cryopreservation of human embryonic stem cells on microcarriers. Biotechnol Prog. 2009;25:20-31.

59. Phillips BW, Horne R, Lay TS, Rust WL, Teck TT, Crook JM. Attachment and growth of human embryonic stem cells on microcarriers. J Biotechnol. 2008;138:24-32.

60. Lock LT, Tzanakakis ES. Expansion and Differentiation of Human Embryonic Stem Cells to Endoderm Progeny in a Microcarrier StirredSuspension Culture. Tissue Eng Part A. 2009;15:2051-2063.

61. Oh SK, Chen AK, Mok Y, Chen X, Lim UM, Chin A, Choo AB, Reuveny S. Long-term microcarrier suspension cultures of human embryonic stem cells. Stem Cell Res. 2009;2:219-230. 
62. Kehoe DE, Jing D, Lock LT, Tzanakakis ES. Scalable stirred-suspension bioreactor culture of human pluripotent stem cells. Tissue Eng Part A. 2010;16:405-421.

63. Fernandes AM, Marinho PA, Sartore RC, Paulsen BS, Mariante RM, Castilho LR, Rehen SK. Successful scale-up of human embryonic stem cell production in a stirred microcarrier culture system. Braz J Med Biol Res. $2009 ; 42: 515-522$.

64. Leung HW, Chen A, Choo AB, Reuveny S, Oh SK. Agitation can Induce Differentiation of Human Pluripotent Stem Cells in Microcarrier Cultures. Tissue Eng Part C Methods. 2011;17:165-172.

65. Serra M, Brito C, Sousa MF, Jensen J, Tostoes R, Clemente J, Strehl R, Hyllner J, Carrondo MJ, Alves PM. Improving expansion of pluripotent human embryonic stem cells in perfused bioreactors through oxygen control. $\mathrm{J}$ Biotechnol. 2010;148:208-215.

66. Storm MP, Orchard CB, Bone HK, Chaudhuri JB, Welham MJ. Threedimensional culture systems for the expansion of pluripotent embryonic stem cells. Biotechnol Bioeng. 2010;107:683-695.

67. Lecina M, Ting S, Choo A, Reuveny S, Oh S. Scalable platform for human embryonic stem cell differentiation to cardiomyocytes in suspended microcarrier cultures. Tissue Eng Part C Methods. 2010;16:1609-1619. 
68. Steiner D, Khaner H, Cohen M, Even-Ram S, Gil Y, Itsykson P, Turetsky T, Idelson M, Aizenman E, Ram R, Berman-Zaken Y, Reubinoff B. Derivation, propagation and controlled differentiation of human embryonic stem cells in suspension. Nat Biotechnol. 2010;28:361-364.

69. Singh H, Mok P, Balakrishnan T, Rahmat SN, Zweigerdt R. Up-scaling single cell-inoculated suspension culture of human embryonic stem cells. Stem Cell Res. 2010;4:165-179.

70. Krawetz R, Taiani JT, Liu S, Meng G, Li X, Kallos MS, Rancourt DE. Large-scale expansion of pluripotent human embryonic stem cells in stirredsuspension bioreactors. Tissue Eng Part C Methods. 2010;16:573-582.

71. Olmer R, Haase A, Merkert S, Cui W, Palecek J, Ran C, Kirschning A, Scheper T, Glage S, Miller K, Curnow EC, Hayes ES, Martin U. Long term expansion of undifferentiated human iPS and ES cells in suspension culture using a defined medium. Stem Cell Res. 2010;5:51-64.

72. Ladewig J, Koch P, Endl E, Meiners B, Opitz T, Couillard-Despres S, Aigner L, Brustle O. Lineage selection of functional and cryopreservable human embryonic stem cell-derived neurons. Stem Cells. 2008;26:1705-1712. 
73. Kim YY, Ku SY, Liu HC, Cho HJ, Oh SK, Moon SY, Choi YM.

Cryopreservation of Human Embryonic Stem Cells Derived-Cardiomyocytes Induced by BMP2 in Serum-Free Condition. Reprod Sci. 2011;18:252-260.

74. de Peppo GM, Sjovall P, Lenneras M, Strehl R, Hyllner J, Thomsen P, Karlsson C. Osteogenic potential of human mesenchymal stem cells and human embryonic stem cell-derived mesodermal progenitors: a tissue engineering perspective. Tissue Eng Part A. 2010;16:3413-3426.

75. Gruenloh W, Kambal A, Sondergaard C, McGee J, Nacey C, Kalomoiris S, Pepper K, Olson S, Fierro F, Nolta JA. Characterization and in vivo testing of mesenchymal stem cells derived from human embryonic stem cells. Tissue Eng Part A. 2011;17:1517-1525.

76. Xu C, Police S, Hassanipour M, Li Y, Chen Y, Priest C, O'Sullivan C, Laflamme MA, Zhu WZ, Van Biber B, Hegerova L, Yang J, Delavan-Boorsma K, Davies A, Lebkowski J, Gold JD. Efficient generation and cryopreservation of cardiomyocytes derived from human embryonic stem cells. Regen Med. 2011;6:53-66.

77. Schlegel PG, Wolfl M, Schick J, Winkler B, Eyrich M. Transient loss of consciousness in pediatric recipients of dimethylsulfoxide (DMSO)cryopreserved peripheral blood stem cells independent of morphine comedication. Haematologica. 2009;94:1473-1475. 
78. Wolkers WF, Tablin F, Crowe JH. From anhydrobiosis to freeze-drying of eukaryotic cells. Comp Biochem Physiol A Mol Integr Physiol. 2002;131:535543.

79. Day JG, Stacey GN. Biobanking. Mol Biotechnol. 2008;40:202-213.

80. Han Y, Quan GB, Liu XZ, Ma EP, Liu A, Jin P, Cao W. Improved preservation of human red blood cells by lyophilization. Cryobiology. 2005;51:152-164.

81. Ono T, Mizutani E, Li C, Wakayama T. Nuclear transfer preserves the nuclear genome of freeze-dried mouse cells. J Reprod Dev. 2008;54:486-491.

82. Natan D, Nagler A, Arav A. Freeze-drying of mononuclear cells derived from umbilical cord blood followed by colony formation. PLoS One. 2009;4:e5240.

83. Puhlev I, Guo N, Brown DR, Levine F. Desiccation tolerance in human cells. Cryobiology. 2001;42:207-217.

84. Gordon SL, Oppenheimer SR, Mackay AM, Brunnabend J, Puhlev I, Levine F. Recovery of human mesenchymal stem cells following dehydration and rehydration. Cryobiology. 2001;43:182-187. 
85. Lynch AL, Chen R, Dominowski PJ, Shalaev EY, Yancey RJ Jr, Slater NK. Biopolymer mediated trehalose uptake for enhanced erythrocyte cryosurvival. Biomaterials. 2010;31:6096-6103.

86. Zhang W, Rong J, Wang Q, He X. The encapsulation and intracellular delivery of trehalose using a thermally responsive nanocapsule. Nanotechnology. 2009;20:275101.

87. Guo N, Puhlev I, Brown DR, Mansbridge J, Levine F. Trehalose expression confers desiccation tolerance on human cells. Nat Biotechnol. 2000;18:168-171.

88. Eroglu A, Russo MJ, Bieganski R, Fowler A, Cheley S, Bayley H, Toner M. Intracellular trehalose improves the survival of cryopreserved mammalian cells. Nat Biotechnol. 2000;18:163-167.

89. Holovati JL, Acker JP. Emerging Role for Use of Liposomes in the Biopreservation of Red Blood Cells. Transfus Med Hemother. 2011;38:99106. 


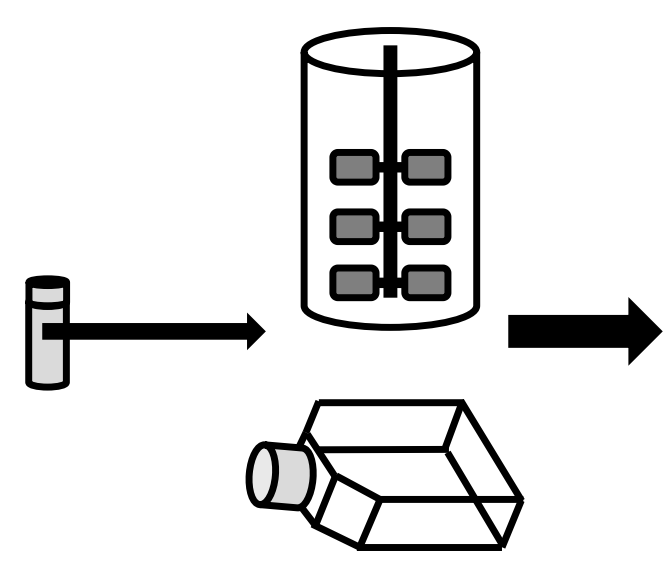

MCB
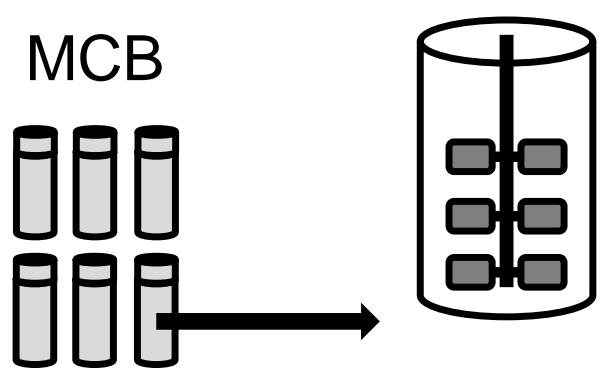

WCB
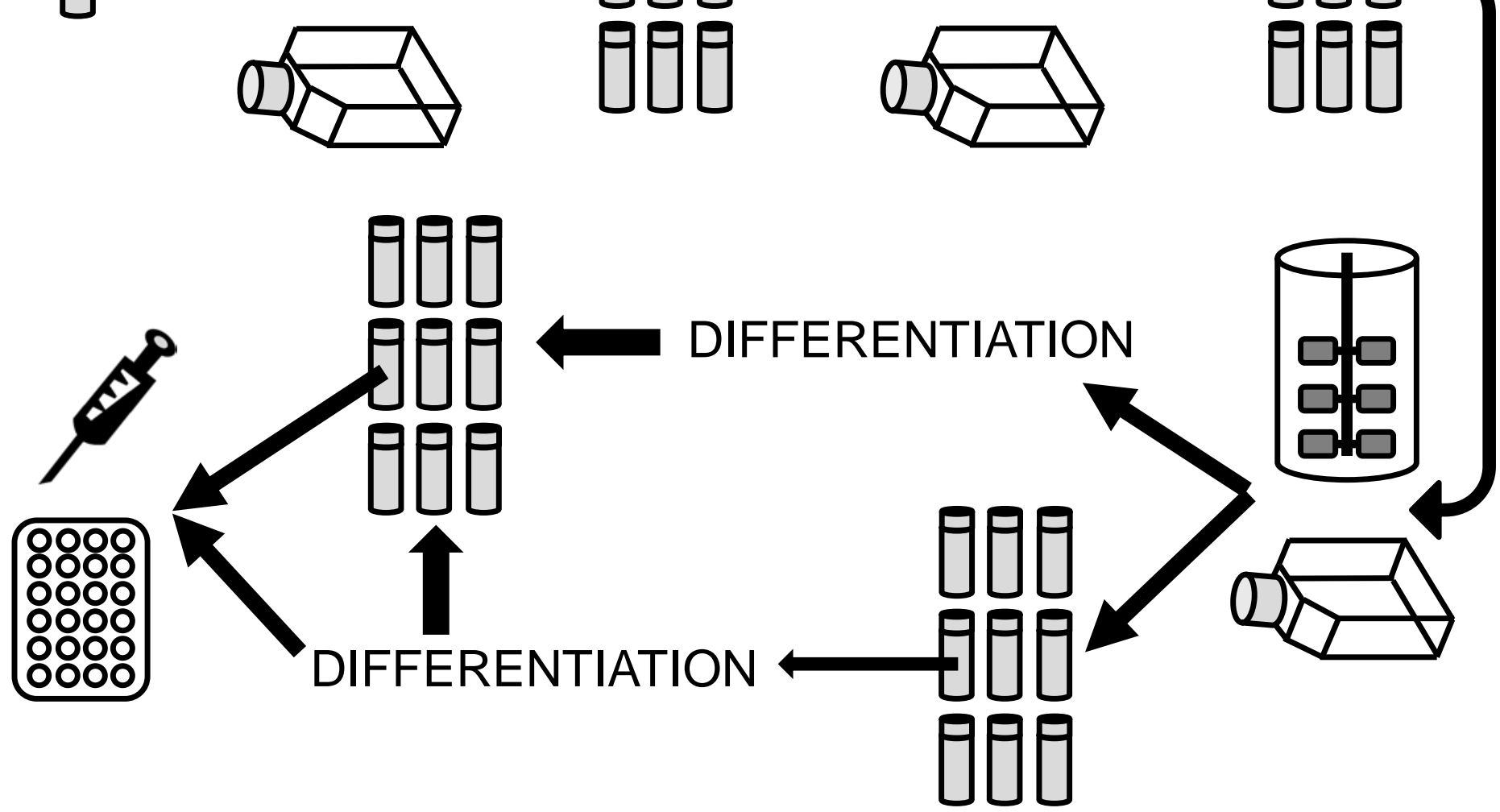

Figure 1. Stages during the culture process when hESCs or their derived progeny may be preserved. A schematic to show sequential expansion and banking of cells. A master cell bank (MCB) could contain $\leq 400$ cryovials, each preserving $\leq 10^{7}$ cells. ${ }^{79}$ One vial of the MCB would be used to generate the subsequent working cell bank (WCB). Notably, hESCderived cells could also be expanded prior to being preserved or utilised but this has been omitted for clarity. 
- Water continues to be drawn out of the cell, causing shrinkage.

Formation of extracellular ice leads to creation of an osmotic imbalance, drawing water out of the cell.

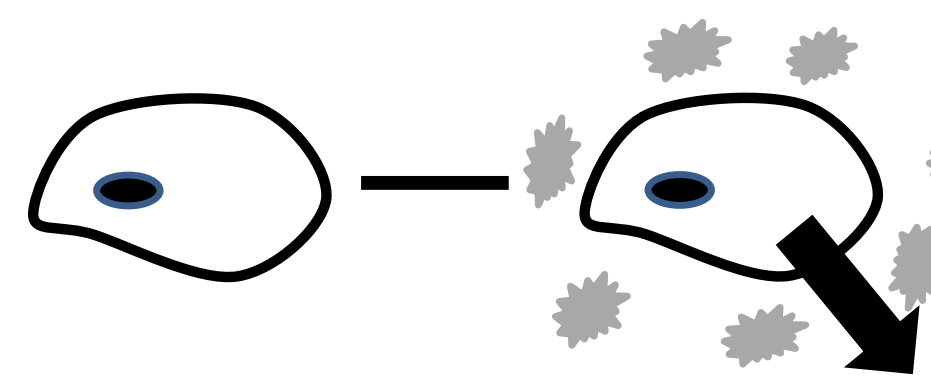

\section{Ice crystals} $y$ Flow of water

西

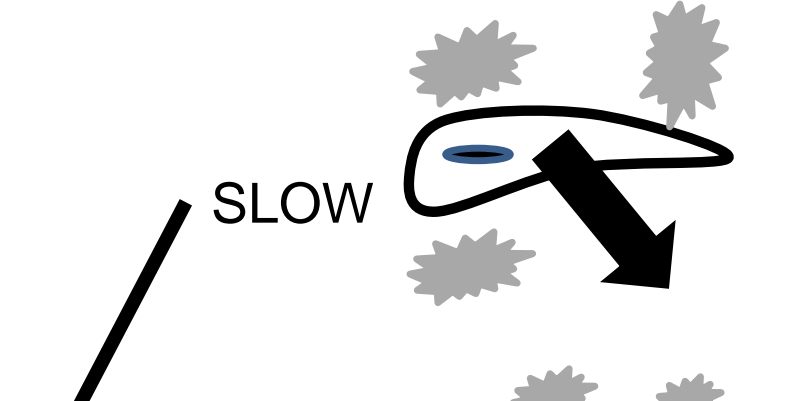

- The osmotic imbalance may be severe enough to concentrate intracellular solutes to toxic levels.

\section{Intracellular ice forms} because insufficient dehydration has occurred.

VERY RAPID

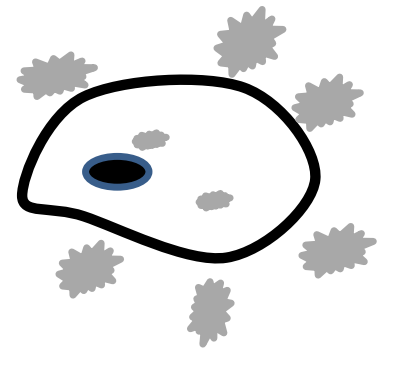

$<-10^{\circ} \mathrm{C}$

Figure 2. Schematic of the key stresses incurred by cells during freezing. If sufficiently high cooling rates can be attained vitrification may be achieved (not shown). Notably, spontaneous formation of extracellular ice can only occur when the extracellular solution is cooled below its equilibrium melting point (e.g. $\sim 10^{\circ} \mathrm{C}$ ). During slow freezing protocols, when extracellular ice formation is encouraged, ice is commonly deliberately seeded at -1 to $-5^{\circ} \mathrm{C}$ by touching the sample with a pre-chilled needle. This manual seeding avoids additional cell damage which can be caused by the spontaneous formation of ice crystals in supercooled solutions. ${ }^{22-26}$ Based on Figure 1 from ${ }^{24}$. 


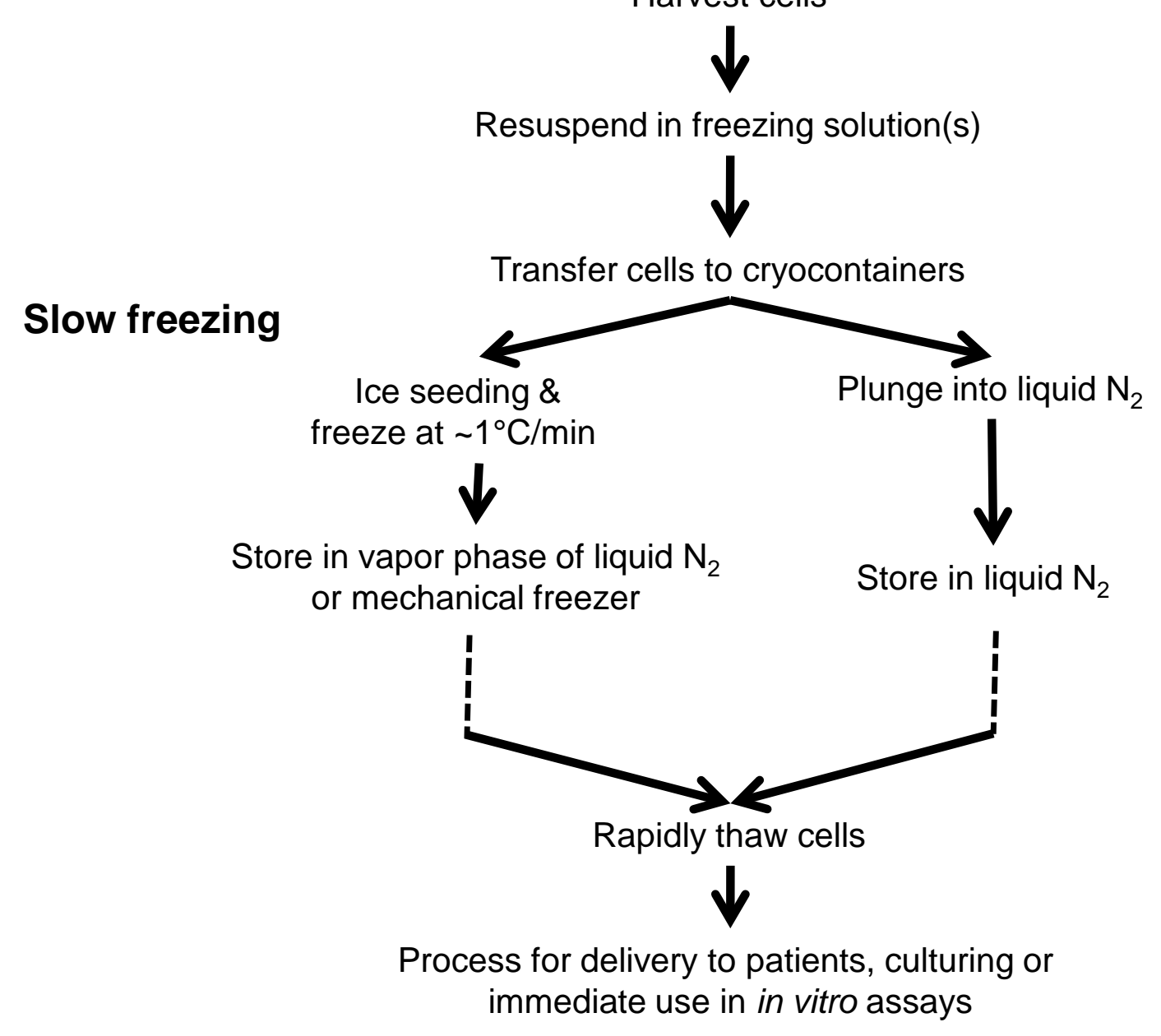

\section{Vitrification}

Ice seeding \& freeze at $\sim 1^{\circ} \mathrm{C} / \mathrm{min}$

Figure 3. Outline of typical processing steps in conventional slow freezing and vitrification. Cells are first harvested from their culture environment. As hESCs are adherent, this involves either a mechanical or enzymatic dissociation step into either clumps or single cell suspensions. Slow freezing: cells are usually exposed to the cryopreservation medium containing CPA(s) and quickly transferred into cryocontainers (e.g. $1 \mathrm{ml}$ cryovial), although stepwise addition of CPAs is sometimes done. Manual ice seeding is typically carried out before vials are then cooled at a controlled rate to at least $-80^{\circ} \mathrm{C}$. These are subsequently stored long term in the vapour phase of liquid nitrogen. Following rapid thawing, cells are transferred into prewarmed growth medium in order to dilute out the CPA(s). Vitrification: $\sim 5$ clumps of cells are manually transferred through at least two vitrification solutions containing CPA(s) before being placed in a cryocontainer (e.g. a cryostraw) and plunged directly into liquid nitrogen. Stepwise exposure to CPAs is used to avoid osmotic stress and toxicity. Rapid thawing is achieved by plunging the vitrified cells directly into pre-warmed media, although again several thawing media are used to 


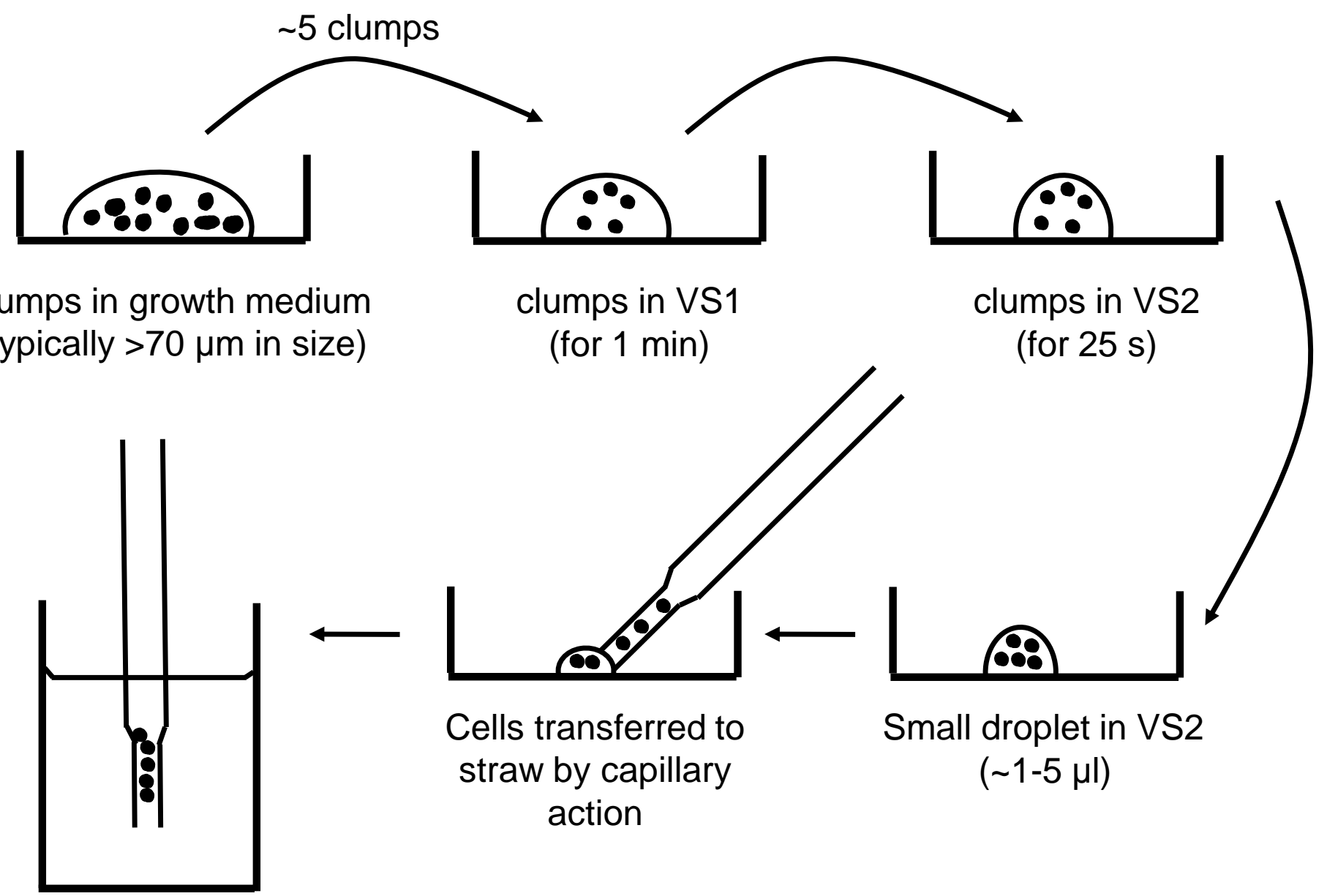

Straw rapidly immersed

in liquid nitrogen

Figure 4. Outline of the OPS method of vitrification commonly used to preserve hESCs grown in colonies. Colonies of cells are first dissected into smaller clumps before being processed as shown. Based on the methods detailed in ${ }^{12,35}$. 